\title{
$\mathrm{SDR}$ 기반 디지털 위성 트랜스폰더를 위한 가변 표본화율의 재귀 연산 구조
}

백 대 성*, 임 원 규", 김 종 훈

\section{A Variable Sample Rate Recursive Arithmetic Half Band Filter for SDR-based Digital Satellite Transponders}

\author{
Dae-sung Baek*, Won-gyu Lim*, Chong-hoon Kim \\ 요 약
}

위성 트랜스폰더의 설계에 있어서 위성체의 제한된 전원자원으로 인해 연산 알고리즘의 최소화와 하드웨어 구 현에 필요한 연산 및 논리 자원의 최소화가 필수적이다. 아울러 위성의 환경에 따라 다양한 대역폭에 대한 효율적 신호처리가 요구되는데 이러한 조건들은 SDR기반의 디지털 방식 구현에 적합하다. 본 논문에서는 SDR 기반의 위 성 트랜스폰더 수신부에서 반송파와 레인징 및 Command 부밴드 신호에 대해 각각의 대역과 데이터율을 가변적으 로 선택 할 수 있는 하향 표본화기를 제안하였다. 제안된 하향표본화기는 한 개의 하프밴드 필터로부터 재귀적 연 산구조를 통해 다수의 임의의 $2^{\mathrm{M}}$-하향 표본화된 신호를 얻을 수 있으며, 연산량 및 구현에 따르는 논리자원을 최 소화 할 수 있다. 또한 재귀적 연산 하드웨어 구현을 위한 알고리즘과 함께 하향표본화에 따르는 대역평탄도 및 에일리어싱을 분석하고 이를 FPGA 실험을 통하여 동작 및 성능을 입증하였다.

Key Words : Half Band Filter, Recursive Arithmetic, SDR, Transponder, Filter Chain

\section{ABSTRACT}

Due to the limited power supply resources, it is essential that the minimization of algorithmic operation and the reduction of the hardware logical-resources in the design of the satellite transponder. It is also required that the transponder process the signals of various bandwidth efficiently, that is suitble for the SDR-based implementation. This paper proposes a variable rate down sampler which can provide variable bandwidth and data rate for carrier, ranging and sub-band command signals respectively. The proposed down sampler can provide multiple $2^{\mathrm{M}}$ decimated outputs from a single half band filter with recursive arithmetic architecture, which can minimize the hardware resources as well as the arithmetic operations. The algorithm for hardware implementation as well as the analysis for the passband flatness and aliasing is presented and varified by the FPGA implementation.

\section{I. 서 론}

위성-지상국 또는 위성-위성 간의 통신을 위하여 위
성에 탑재되는 트랜스폰더의 수신 시스템은 위성의 용도에 따라 매우 다른 통신환경에 직면하게 된다. 예 를 들어 근궤도 위성에서 수신되는 지상국 신호의

- First Author : 숭실대학교 정보통신전자 공학부 무선통신시스템연구실, daesungb@gmail.com, 학생회원

${ }^{\circ}$ Corresponding Author : 숭실대학교 정보통신전자 공학부 무선통신시스템연구실, chkim@ssu.ac.kr, 정회원

* 한국 항공우주연구원,wglim@ kari.re.kr

논문번호 : KICS2013-05-215, 접수일자 : 2013년 5월 23일, 심사일자 : 2013년 5월 30일, 최종논문접수일자 : 2013년 12월 9일 
$\mathrm{SNR}$ 이 비교적 큰 관계로 고속의 통신이 가능한 반면 심우주(Deep Space)탐사선의 경우 지구와의 거리에 따라 SNR 확보를 위하여 수백Kbps에서 수 bps까지의 다양한 비트율이 제공되어야 한다 ${ }^{[1]}$. SDR(Software Defined Radio) 개념의 디지털 수신기는 이러한 다양 한 비트율을 하나의 하드웨어 안에서 제공할 수 있도 록 설계되어야 하며, 이를 위한 디지털 신호처리 구조 는 입력 데이터를 여러 단계로 하향 표본화(Down Sampling) 하고, 각 단계별로 신호를 선택할 수 있도 록 단계별 출력을 다중화기(Multiplexer)를 통해 디지 털 복조기에 입력하는 구조가 된다. 한편 위성에 탑재 되는 전자 장비는 극한의 온도와 고 에너지 우주선 (Cosm ic Ray)과 같은 우주환경에서 동작의 신뢰도를 확보하기위해 고장허용시스템(Fault Tolerant Sys tem)으로 구성되어야 하며 주로 TMR(Triple Modular Redundancy)구조를 사용하는데, 이 경우 하나의 디지 털 신호처리 블록을 구성하는데 상용 시스템의 약 3 배의 하드웨어 자원이 소요되며, 이는 위성체의 제한 된 전원자원과 진공에서의 열 방출문제로 인해 시스 템 설계에 많은 제약을 받게 된다. 따라서 위성 트랜 스폰더의 수신기 설계에 있어서 하드웨어 자원을 최 소화 하면서 임의의 하향 표본화가 가능한 디지털 신 호처리 구조의 설계는 대단히 중요한 문제이다. 이러 한 배경을 고려할 때 Zero-Pha se FIR 타입 하프밴드 필터(HBF) 는 다상 필터 뱅크 구조로 구현하면 곱셈 연산량이 계수 수의 $1 / 4$ 인 매우 효율적인 하드웨어 구성이 가능하며, 재표본화기(Resampler)는 임의의 유리수 비로 표본화율을 변경할 수 있으므로, 그림 (1-a) 와 같이 $\mathrm{M}$ 개의 $\mathrm{HBF}$ 를 연결하고 각 출력중 하 나를 선택하여 표본화율 $\alpha(0.5 \leq \alpha \leq 1)$ 로 재표본 화하면 출력신호의 데이터율과 입력신호의 데이터율 의 비를 $\beta$ 라 할 때 $1 / 2 \geq \beta \geq 2^{-(M+1)}$ 범위 내에서 임의의 표본율을 구현할 수 있다. 본 논문에서는 하나 의 $\mathrm{HBF}$ 에서 동일한 계수로 여러 단의 $\mathrm{HBF}$ 연산을 수행하면서 최종 출력에서 에일리어싱(Aliasing)이 없 는 재귀적 $\mathrm{HBF}$ 구조를 제안하며(그림 1-b), 그 하드웨 어 구조를 $\mathrm{VHDL}$ 코드로 작성하여 모의실험을 통해 성능을 검증하고 Xilinx Virtex5 FPGA에 구현하여 논리자원의 최소화를 입증하였다.

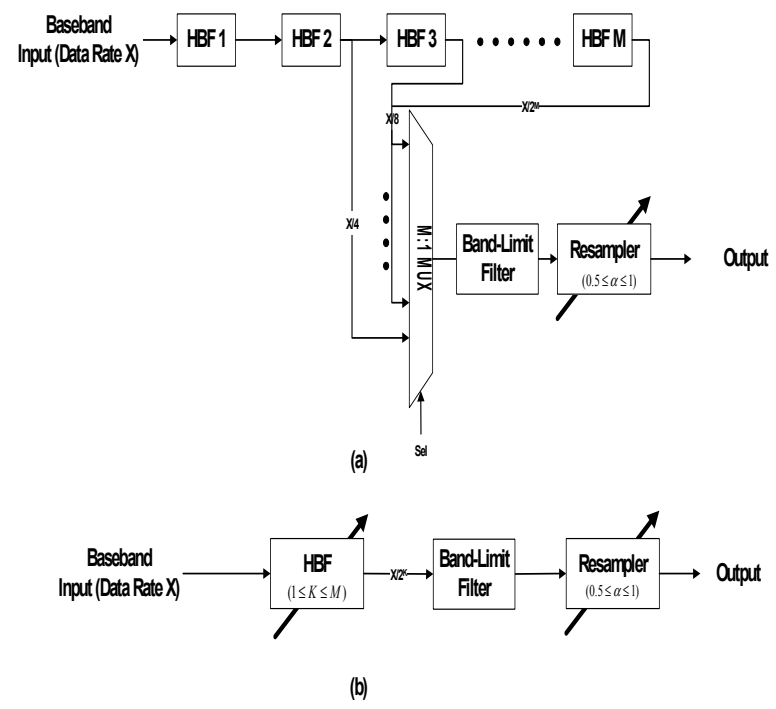

그림 1. $\mathrm{M}$ 개의 $\mathrm{HBF}$ 를 사용한 하향표본화기(a) 와 등 가인 한 개의 재귀연산 구조 $\mathrm{HBF}$ 를 사용한 하향 표본화기 Fig. 1. Down Sampler with M-Stage HBF's (a) and Equival ent Down Sampler using a signle recursive arithmetic $\operatorname{HBF}(b)$

\section{II. 재귀 연산 구조의 HBF 특성}

\section{1. 동일 계수의 M단 Zero-Phase 타입 $\mathrm{HBF}$ 하향 표본화기 특성}

실수 계수의 Zero-Phase FIR 타입 $\mathrm{HBF}$ 는 $4 \mathrm{~N}+3$ 개 의 계수를 가지며 임펄스 응답은 다음과 같은 특징 을 가지고 있다 ${ }^{[2]}$.

$$
h(n)=h(-n), \quad h(2 n)= \begin{cases}1 & n=0 \\ 0 & \text { otherwise }\end{cases}
$$

이러한 $\mathrm{HBF}$ 의 주파수 응답을 $H\left(e^{j \omega}\right)$ 라 할 때 그 응답특성은 위상값이 항상 0 이며, 진폭 응답이 $\pi / 2$ 를 중심으로 대칭이다. 이를 수학적으로 표현하 면 다음과 같다.

$$
\left|H\left(e^{j \omega}\right)\right|=H\left(e^{j \omega}\right), \quad H\left(e^{j \omega}\right)+H\left(e^{j(\pi-\omega)}\right)=1
$$

여기서 $0 \leq \omega \leq \omega_{p}$ 인 주파수 $\omega$ 에 대하여 $1-\delta \leq\left|H\left(e^{j \omega}\right)\right| \leq 1+\delta$ 인 $\omega_{p}$ 를 차단주파수, 대역 $\left[-\omega_{p}, \omega_{p}\right]$ 를 통과대역, $\quad\left[\pi-\omega_{p}, \pi+\omega_{p}\right]$ 를 차단대역 이라 각각 정의하면 식(2)로부터 차단대역의 진폭 응답은 $\left|H\left(e^{j \omega}\right)\right| \leq \delta$ 를 만족한다. 이러한 $\mathrm{HBF} \mathrm{M}$ 개를 직렬로 연결 했을 때 출력의 응답특성을 $H_{M}\left(e^{j \omega}\right)$ 라 하면 


$$
H_{M}\left(e^{j \omega}\right)=\prod_{k=1}^{M} H\left(e^{j k \omega}\right)
$$

이며, $\mathrm{K}$ 번째 $\mathrm{HBF}$ 의 특성 $H\left(e^{j K \omega}\right)$ 에 대하여 $A_{K}(m)$ 을

$$
\begin{aligned}
& A_{K}(m) \equiv {\left[\left(\mathrm{m} \pi-\omega_{\mathrm{p}}\right) 2^{-(\mathrm{K}-1)},\left(\mathrm{m} \pi+\omega_{\mathrm{p}}\right) 2^{-(\mathrm{K}-1)}\right] } \\
&,\left(0 \leq m<2^{K}\right)
\end{aligned}
$$

로 정의할 때 $A_{K}(m)$ 의 특성은 다음과 같다.

(1) $A_{K}(0)$ 는 통과 대역

(2) $\mathrm{m}$ 이 0 이 아닌 짝수 이면 $A_{K}(0)$ 는 에일리 어싱을 일으키는 대역이며 $A_{K}(2 m) \subset A_{K-1}(m)$ 이 다.

(3) $\mathrm{m}$ 이 홀수 이면 $A_{K}(m)$ 는 차단대역

특성 (1),2) 및 (3)으로부터 $M$ 단의 동일 계수 $\mathrm{HBF}$ 하향 표본화기에서 최종 단의 통과대역은 이전 $1 \sim M-1$ 단의 통과대역에 속하며, 에일리어싱 대역 은 $1 \sim M-1$ 단의 차단대역중 적어도 하나의 차단대 역 내에 속하여 최종단의 모든 에일리어싱 대역에서 신호 소거비가 $\delta$ 이하임을 알 수 있다. 그림 2 는 3 단 $\mathrm{HBF}$ 하향 표본화기의 응답특성을 그린 것이다. 사용 된 $\mathrm{HBF}$ 는 11 개의 계수를 가지며 통과 대역 $0.23 \pi$, 차단 대역 신호소거비 $\delta=-60[\mathrm{~dB}]$ 로 설계된 필터이 다. 왼쪽의 검은 영역이 통과 대역이고 빗금으로 채워 진 영역이 에일리어싱 대역이며, 에일리어싱 대역의 응답은 설계된 필터의 차단대역 신호소거비 보다 적 음을 알 수 있다. 한편 $\mathrm{M}$ 단 $\mathrm{HBF}$ 의 물리적인 최종 표 본화율을 $f_{s}[\mathrm{~Hz}]$ 라 할 때 통과대역 $f_{p}$ 는 $f_{p}=\omega_{p} f_{s} / \pi$ $[\mathrm{Hz}]$ 이며, 식(2)에 의해 $f_{p}$ 부터 Nyquist주파수 $f_{s} / 2$ 에 이르는 과도대역은 에일리어싱을 피할 수 없다. 따 라서 최종적으로 이 대역은 차단되어야 하며 이를 위 해 그림 1 과 같이 $\mathrm{M}$ 단 필터 뒤에 대역차단 필터를 사 용하여야한다. 한편 통과대역 내에서 리플은 각 단의 리플의 곱이 되나 $\mathrm{M}$ 값이 커질 수록 앞단에서의 리플 은 적어지고 $\mathrm{DC}$ 응답에 가까워 지므로 리플이 리플 이 늘어나지 않고 일정한 값에 수렴한다. 그림 3 은 5 종류의 다른 탭 수를 가진 Parks-McClellan HBF 필 터에 대하여 $\mathrm{M}$ 값에 따른 통과대역 리플을 나타낸 것 이다. $\mathrm{M}$ 값이 5 이상이 되면 리플이 일정한 값에 수렴 함을 관찰할 수 있다.

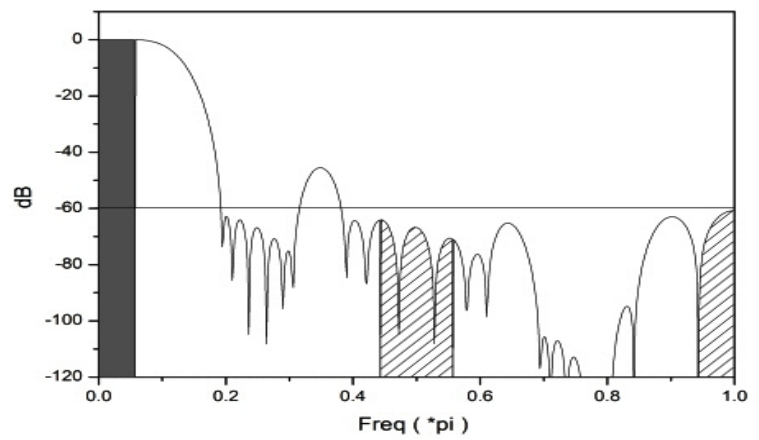

그림 2. 직렬 Zero-Phase FIR HBF 하향표본화기의 주파수 응답 $(\mathrm{M}=3, \mathrm{Ntap}=11)$

Fig. 2. Frequency Response of Cascaded Zero- Phase FIR $\mathrm{HBF}$ Down Sampler $(\mathrm{M}=3, \mathrm{Ntap}=11)$

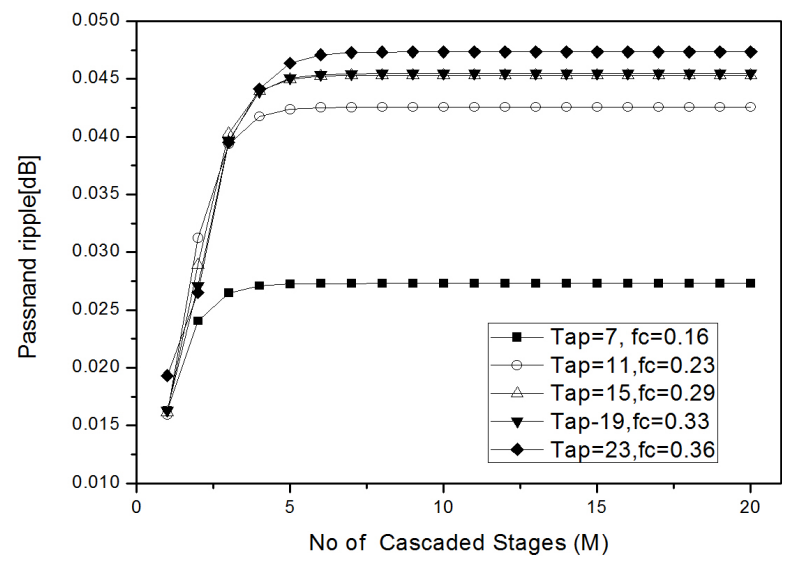

그림 3. M 값에 따른 통과대역 리플의 변화 (fc 는 통과대 역 최대주파수)

Fig 3. Passband ripple with respect to $M$ (fc is the maximum passband frequency)

\subsection{M단 $\mathrm{HBF}$ 하향 표본화기의 연산량과 출력 데이터율}

식 (1)과 같은 특성을 가진 $4 \mathrm{~N}+3$ 계수의 $\mathrm{HBF}$ 를 사 용한 하향 표본화기를 2 채널의 다상필터 뱅크 방식으 로 구현할 때 한 채널은 $2 \mathrm{~N}$ 개의 대칭 계수 FIR 필터 로 구성되고 다른 한 채널은 0.5 값을 가지는 하나의 계수와 나머지 계수의 값이 0 인 FIR 필터로 구성되며, 전자의 경우 대칭 필터이므로 $\mathrm{N}$ 회의 곱셈 및 누산 연 산(Multiplic ation - Accumulatioon:MAC)이 필요하 고, 후자의 경우 곱셈 연산 없이 신호의 지연만으로 구현될 수 있다. 이 때 입력 신호의 주기를 $T$ [Sec] 라 하고 대칭계수 FIR 채널의 연산기간이 $\tau(\leq T)$ 이하라 가정하면 $\mathrm{HBF}$ 의 출력 주기는 $2 T$ 이고 단위 시간당 $\mathrm{MAC}$ 비율은 $\tau / 2 T$ 이다. 이러한 $\mathrm{HBF} \mathrm{M}$ 개를 직렬로 연결했을 때 $k$ 번째 $(1 \leq k \leq M) \mathrm{HBF}$ 의 입 력 주기는 $1 / 2^{k-1} T$ 이며 단위시간당 $\mathrm{MAC}$ 비율을 
$M A C(k)$ 라 하면 $M A C(k)=\tau / 2^{k} T$ 로 표현되며 $\mathbf{M}$ 개의 $\mathrm{HBF}$ 전체의 단위시간당 연산비율은

$$
M A C=\sum_{k=1}^{M} 2^{-k} \frac{\tau}{T}=\frac{\left(1-2^{-M}\right) \tau}{T}
$$

로 계산된다. 식(5)에서 $\tau \leq T$ 이면 $\mathrm{M}$ 단 $\mathrm{HBF}$ 의 단 위시간당 MAC 비율은 항상 1 보다 적음을 알 수 있으 며 이는 하나의 $\mathrm{HBF}$ 구조에서 $\mathrm{M}$ 단 $\mathrm{HBF}$ 의 연산을 모두 수행할 수 있음을 시사한다. 그림 4는 3단 $\mathrm{HBF}$ 에서의 $\mathrm{MAC}$ 시간 분포를 나타낸 것이다 $(\tau=T$ 로 가 정). $\mathrm{MAC}$ 연산이 수행되는 구간은 입력 8 샘플당 7 회 이므로 단위 시간당 MAC 비율은 식(5)와 일치함 을 보여준다.

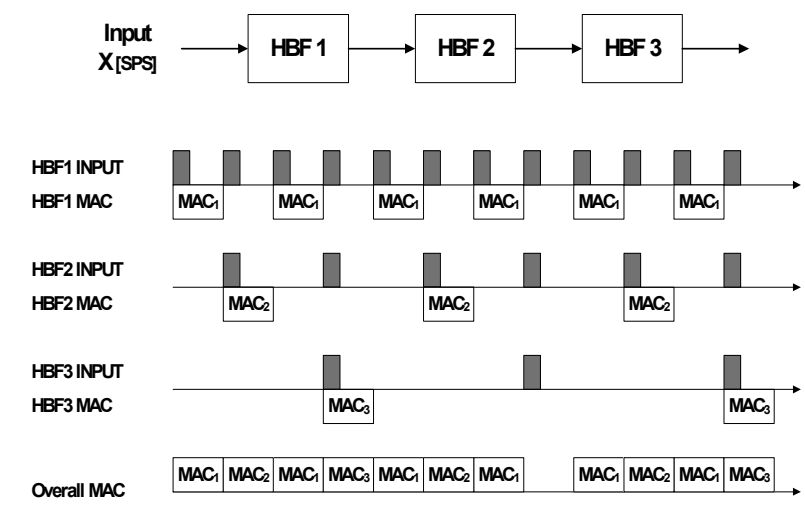

그림 4. 3 단 $\mathrm{HBF}$ 하향 표본화기의 곱셈 및 누산 연산 시 간 분포

Fig. 4. Multiplication and Accumulation (MAC) Time Distribution of 3-Stage HBF Decimator

\section{III. 재귀 연산 구조 HBF 하드웨어 구현}

\section{1. 구현 구조 및 알고리즘}

기본적인 다상필터 구조의 $\mathrm{HBF}$ 구현은 입력 데 이터와 필터 계수를 저장하기 위한 DPRAM과 계 수 저장 ROM, 데이터 지연을 위한 시프트 레지스 터 그리고 $\mathrm{MAC}$ 과 덧셈기로 구현 가능하며, $\mathrm{MAC}$ 에서는 $2 \mathrm{~N}$ 개의 대칭 계수 FIR필터의 경우 $\mathrm{N}$ 개의 곱셈기가 요구되나 필터 동작 클록과 입력 샘플 속 도의 비율(Clock Per Sample rate:CPS)이 N보다 큰 경우 하나의 곱셈기를 사용하여 $\mathrm{MAC}$ 구현이 가능하다. 본 논문에서는 CPS가 앞의 조건을 만족 하는 상황을 가정하여 재귀 연산 구조의 $\mathrm{HBF}$ 를 구 현하였으며, 그림 5 는 본 논문에서 제안하는 재귀 연산 구조 $\mathrm{HBF}$ 구현 구조의 블록도이다.

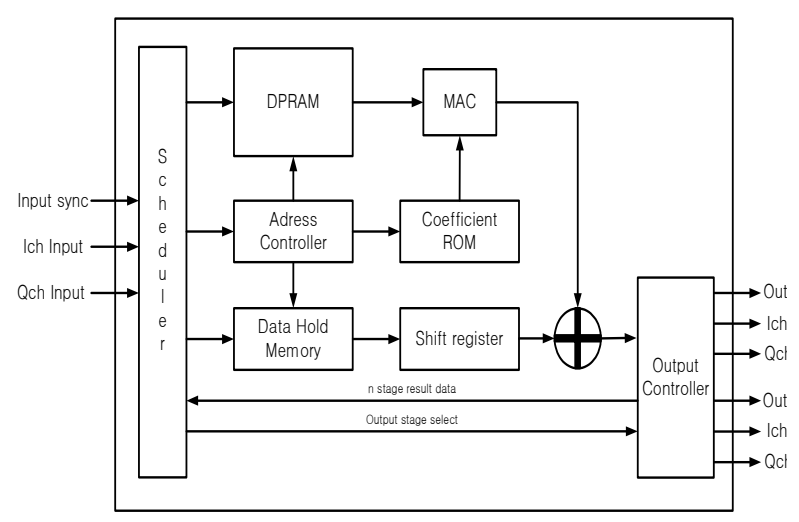

그림 5. 재귀적 하프밴드 필터 구현 블록도

Fig. 5. Recursive Half-Band Filter Block Dia- gram

재귀 연산 구조 $\mathrm{HBF}$ 의 구현은 다상 필터 구조의 $\mathrm{HBF}$ 를 기반으로 다단의 $\mathrm{HBF}$ 동작을 수행하기 위해 각 단의 지연 데이터를 저장하기위한 메모리를 추가 했으며, 사용된 메모리들의 주소제어기와 연산 결과의 궤환과 출력 동작을 제어하는 출력제어기가 사용되었 다. 또한 출력제어기는 다양한 비트율을 제공해야하는 $\mathrm{SDR}$ 기반의 디지털 수신기의 특성에 적합하도록 구 현된 재귀 연산 구조 $\mathrm{HBF}$ 의 각 단의 결과 중 임의로 두 개단의 결과를 출력할 수 있도록 구현하였다. 재귀 연산 구조 $\mathrm{HBF}$ 에서 각 단의 연산 순서 분배와 입력 및 궤환 데이터의 분배를 제어하기 위해 스케줄러가 사용되었으며 그림 6 은 스케줄러에 사용된 알고리즘 을 나타내는 순서도로써 스케줄링을 통한 연산 분배 를 구현하기 위한 알고리즘은 재귀적 하프밴드 필터 의 입력을 카운팅하여 연산분배의 스케줄을 제어하는 방식을 사용하였으며 이때 $K$ 개의 단을 가지는 스케 줄링이 적용된 재귀적 $\mathrm{HBF}$ 의 연산분배를 제어하기 위해서는 $K+1$ 비트의 카운터가 필요하다. 연산 순 서 제어에 사용되는 $K+1$ 비트 카운터의 이름은 Schedule_time으로 설정하였고, 입력신호의 존재를 알리는 i_sync 신호가 입력과 함께 필터에 입력되게 되면 Schedule_time의 값은 1 증가하게 된다. 그 후 Schedule_time의 값을 판단하여 그 값이 0 인 경우 연산이 이루어지지 않는 상태로 판단하게 되며 이 상 태를 null이라고 판단하고 입력된 데이터를 저장하기 만 한다. 그리고 카운터 Schedule_time의 값이 0이 아 닌 경우 Schedule_time의 LSB에서 MSB로 1 비트씩 증가시키며 처음으로 1 의 값을 가지는 비트를 검색하 게 된다. 첫 번째로 검색되는 1 의 값을 가지는 비트가 해당 동작을 수행해야하는 재귀 연산 구조 $\mathrm{HBF}$ 의 단 이 되는 것이다. 즉 Schedule_time(0)가 1의 값을 가 지는 경우 첫 번째 단에 해당하는 동작을 수행하기 위 
한 필터 내부의 메모리 주소로 이동하게 되는 것이다. 하프밴드 필터에서 입력에 대한 두 가지 동작인 입력 을 지연시키는 동작과 메모리에 저장하여 필터계수와 연산을 시작하는 동작에 대한 판단 또한 Schedule _time의 값을 통해서 판단하게 된다. 연산의 순서를 찾기 위해 Shcedule_time의 값을 LSB에서 1비트씩 증가시키며 $l$ 번 째 비트에서 처음 1 의 값을 찾았다면 $l+1$ 번 째 비트의 값을 통해서 해당하는 재귀적 하프 밴드 필터의 단의 동작을 판단하게 된다. $l+1$ 번 째 비트의 값이 0 인 경우 재귀 연산 구조 $\mathrm{HBF}$ 는 이전 단 의 출력을 시프트 레지스터에 입력하기 위해 임시로 그 값을 저장하게 되며, 1 의 값을 가지는 경우 이전 단의 출력을 다시 입력 받아 필터 계수와의 연산 동작 을 시작하게 된다. 표 1 은 3 개 단으로 설정된 경우의 재귀 연산 구조 HBF의 Schedule_ time 값에 따른 연 산 순서 및 상황을 나타낸 표이다.

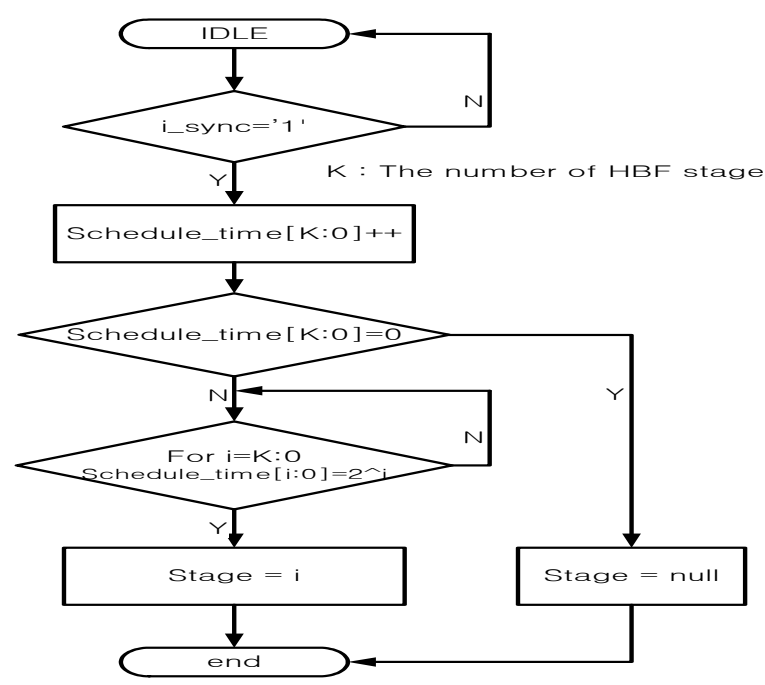

그림 6 . 연산 분배가 적용된 하프밴드 필터의 연산 순서 제어 순서도

Fig. 6. Flow Chart of Scheduling applied Recu rsive Half Band Filter operation control

표 1. Schedule_time 값에 따른 연산 순서 및 상황 Table 1. Operation state according to schedule_time value

\begin{tabular}{|c|c|c|c|}
\hline $\begin{array}{c}\text { Schedule_ } \\
\text { time[3:0] }\end{array}$ & $\begin{array}{c}\text { 연산 순서 및 } \\
\text { 상황 }\end{array}$ & $\begin{array}{c}\text { Schedule_ } \\
\text { time[3:0] }\end{array}$ & $\begin{array}{c}\text { 연산 순서 및 } \\
\text { 상황 }\end{array}$ \\
\hline 0000 & $\begin{array}{c}\text { null } \\
\text { [입력 저장] }\end{array}$ & 1000 & $\begin{array}{c}\text { null } \\
\text { [입력 저장] }\end{array}$ \\
\hline 0001 & $\begin{array}{c}\text { 첫 번째 단 } \\
\text { [입력 저장] }\end{array}$ & 1001 & $\begin{array}{c}\text { 첫 번째 단 } \\
\text { [입력 저장] }\end{array}$ \\
\hline 0010 & $\begin{array}{c}\text { 두 번째 단 } \\
\text { [입력 저장] }\end{array}$ & 1010 & $\begin{array}{c}\text { 두 번째 단 } \\
\text { [입력 저장] }\end{array}$ \\
\hline 0011 & $\begin{array}{c}\text { 첫 번째 단 } \\
\text { [연산 시작] }\end{array}$ & 1011 & $\begin{array}{c}\text { 첫 번째 단 } \\
\text { [연산 시작] }\end{array}$ \\
\hline
\end{tabular}

\begin{tabular}{|c|c|c|c|}
\hline 0100 & $\begin{array}{c}\text { 세 번째 단 } \\
\text { [입력 저장] }\end{array}$ & 1100 & $\begin{array}{c}\text { 세 번째 단 } \\
\text { [연산 시작] }\end{array}$ \\
\hline 0101 & $\begin{array}{c}\text { 첫 번째 단 } \\
\text { [입력 저장] }\end{array}$ & 1101 & $\begin{array}{c}\text { 첫 번째 단 } \\
\text { [입력 저장] }\end{array}$ \\
\hline 0110 & $\begin{array}{c}\text { 두 번째 단 } \\
\text { [연산 시작] }\end{array}$ & 1110 & $\begin{array}{c}\text { 두 번째 단 } \\
\text { [연산 시작] }\end{array}$ \\
\hline 0111 & $\begin{array}{c}\text { 첫 번째 단 } \\
\text { [연산 시작] }\end{array}$ & 1111 & $\begin{array}{c}\text { 첫 번째 단 } \\
\text { [연산 시작] }\end{array}$ \\
\hline
\end{tabular}

\section{2. 모의실험 및 FPGA 구현}

본 논문에서 제안된 재귀 연산 구조의 $\mathrm{HBF}$ 를 $\mathrm{HDL}$ 을 통하여 구현하였으며, 모의 실험에서 구현 된 재귀연산 구조 $\mathrm{HBF}$ 의 검증을 위해서 6단으로 필터의 단을 설정하고 $1 \mathrm{KHz}$ 의 $\mathrm{QPSK}$ 신호를 128 $\mathrm{KHz}$ 로 상향 표본화 하여 필터의 입력으로 사용하 였다. 그림 7은 구현된 6단 재귀 연산 구조 $\mathrm{HBF}$ 모델심 시뮬레이션 결과로 각 단의 연산 순서 제어 에 사용되는 Schedule_time과 각 단의 출력 동기 신호인 Schedule 신호를 나타내는 그림이다. 그림 7 에서와 같이 연산 순서 제어에 사용되는 카운터인 Schedule_time은 입력 동기 신호마다 1씩 증가하게 되며 Schedule_time의 각 비트에 의해 그림 5와 같 은 연산 순서 제어 알고리즘을 수행하게 된다. 재귀 연산 구조 $\mathrm{HBF}$ 의 첫 번째 단 출력은 Schedule _time(0) 비트 값이 1 인 경우에 출력되게 되며 $\mathrm{n}$ 번째 단의 출력은 Schedule_time (n-1) 비트의 값이 1 이고 하위 비트들이 0 인 경우 출력된다.

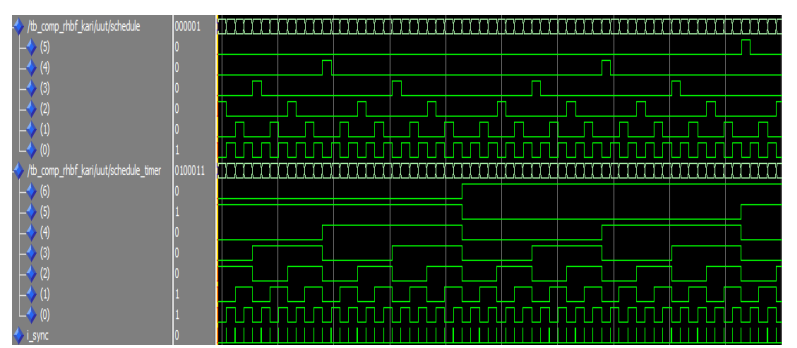

그림 7. 재귀 연산 구조 $\mathrm{HBF}$ 의 연산 스케줄링

Fig. 7. Scheduling of Recursive Arithmetic Half-Band Filter

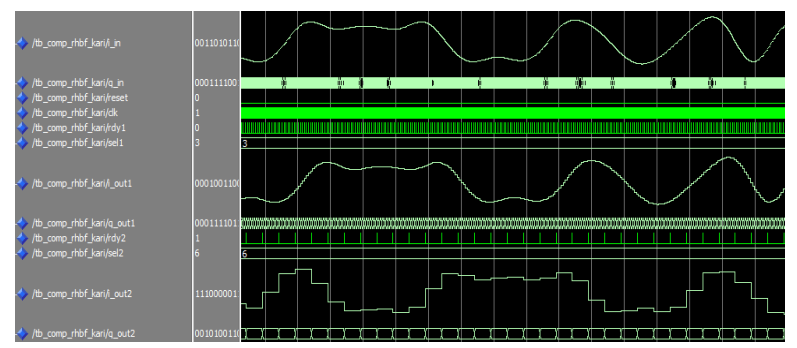

그림 8. 재귀 연산 구조 $\mathrm{HBF}$ 의 I채널 출력

Fig. 8. I channel output of Recursive Arithmetic Half-Band Filter 
그림 8은 구현된 재귀 연산 구조 $\mathrm{HBF}$ 의 I채널 입력과 임의로 설정된 두 개 단의 출력을 나타내는 그림으로써 입력에서 8 하향 표본화 된 재귀 연산 구조 $\mathrm{HBF}$ 의 3 단 출력과 64 하향 표본화된 6단의 출력 결과를 나타낸 그림으로 $\mathrm{HDL}$ 을 통해 구현된 재귀 연산 구조의 $\mathrm{HBF}$ 의 하향 표본화 동작이 정상 적으로 수행되는 것을 검증하였다. 또한 본 논문에 서 제안된 필터를 사용하여 다수의 $\mathrm{HBF}$ 를 대체하 는 경우의 $\mathrm{FPGA}$ 내부 자원 감소를 검증하기 위 해 $\mathrm{I} / \mathrm{Q}$ 채널에서 각 각 6 개의 다상 필터 구조로 구 현된 $\mathrm{HBF}$ 와 제귀 연산 구조 $\mathrm{HBF}$ 를 합성결과를 비 교하였으며, Xilinx ISE 13.2를 사용하여 FPGA 타 겟을 XC5VSX50T로 설정하고 합성을 진행 하였다. 표 2는 합성 결과 중 일부를 나타낸 표이다.

표 2. 합성결과 비교

Table 2. Implementation result

\begin{tabular}{|c|c|c|c|}
\hline $\begin{array}{c}\text { Slice Logic } \\
\text { Utilization }\end{array}$ & FPGA & $\begin{array}{c}\text { 재귀 연산 } \\
\text { 구조 HBF }\end{array}$ & $\begin{array}{c}6 \text { 하프밴드 } \\
\text { 필터 체인 }\end{array}$ \\
\hline $\begin{array}{c}\text { Number of Slice } \\
\text { logic }\end{array}$ & 32,640 & $564(1 \%)$ & $2,269(6 \%)$ \\
\hline $\begin{array}{c}\text { Number of Slice } \\
\text { LUTs }\end{array}$ & 32,640 & $572(1 \%)$ & $2,245(6 \%)$ \\
\hline $\begin{array}{c}\text { Number used as } \\
\text { logic }\end{array}$ & 32,640 & $402(1 \%)$ & $1,392(4 \%)$ \\
\hline $\begin{array}{c}\text { Number used as } \\
\text { Memory }\end{array}$ & 12,480 & $168(1 \%)$ & $841(6 \%)$ \\
\hline $\begin{array}{c}\text { Number of } \\
\text { occupied Slices }\end{array}$ & 8,160 & $331(4 \%)$ & $883(10 \%)$ \\
\hline $\begin{array}{c}\text { Number of } \\
\text { DSP48Es }\end{array}$ & 288 & $2(1 \%)$ & $12(4 \%)$ \\
\hline
\end{tabular}

표 2의 합성 결과를 통하여 연속적으로 사용되는 다수의 하프밴드 필터를 하나의 재귀 연산 구조의 $\mathrm{HBF}$ 로 대체하게 되면 FPGA 내부의 자원 소모가 감소된다는 것을 확인 하였으며, 특히 곱셈 연산에 소모되는 $\mathrm{DSP} 48 \mathrm{E}$ 의 경우에는 $\mathrm{M}$ 개의 연속적으로 사용되는 $\mathrm{HBF}$ 를 재귀 연산 구조 $\mathrm{HBF}$ 로 대체하는 경우 제안된 구조의 필터에서는 $\mathrm{I} / \mathrm{Q}$ 채널 각 각 1 개의 곱셈기가 사용되므로 그 소모량이 $1 / \mathrm{M}$ 으로 감 소된다는 것을 확인하였다.

\section{$\mathrm{IV}$. 결 론}

본 논문에서는 SDR 기반의 디지털 수신기 내부 에서 다양한 데이터 비트율을 제공하기 위해 반복 적으로 사용되는 $\mathrm{HBF}$ 를 대체 가능한 재귀 연산 방 식을 적용한 $\mathrm{HBF}$ 구조를 제안하고 그 특성을 분석 하였다. 또한 재귀 연산 구조 $\mathrm{HBF}$ 구현을 위한 알
고리즘을 제안하고 모의실험과 FPGA 합성 결과를 통하여 다수의 $\mathrm{HBF}$ 를 하나의 재귀 연산 구조 $\mathrm{HBF}$ 로 대체 가능함과 실제 적용시 FPGA 내부의 자원 소모가 감소됨을 보였으며, 이를 통해 다양한 데이 터 비트율을 제공하며 한정된 자원을 효율적으로 사용하여 구현해야하는 SDR 기반의 디지털 위성 트랜스 폰더의 수신기에 적합함을 보였다.

\section{References}

[1] P. P. Vaidyanathan and T. Q. Nguyen, "A trick for the design of FIR half-band filters," IEEE Trans. Circuits Syst., vol. 34, no. 3, pp. 297 - 300, Mar. 1987.

[2] P. P. Vaidyanathan, Multirate Systems and Filter Banks, Prentice Hall, 1993.

[3] R. E. Crochiere and L. R. Rabiner, Multirate Digital Signal Processing, Prentice Hall, 1983.

[4] J.B erner et al., "The NASA Spacecraft Transponding Modem“, Aero space Confe rence Proceedings, 2000 IEEE, Vol.7 ,pp. 195 209, March, 2000

[5] L. Simone et al. "A novel digital platform for deep space transponders: the receiver side." Proc. of IEEE 2004 Aerospace Conference, vol. 03, pp. 1432-1445, Feb, 2004.

[6] K.-N. Seo, S.-W. Choi, and C.-H. Kim, "A SNR estimation algorithm for digital satellite transponder," J. Korea Infom. Commun. Soc. (KICS), vol. 35, no. 9, pp. 729-734, Jan, 2010.

백 대 성 (Dae-sung Baek)

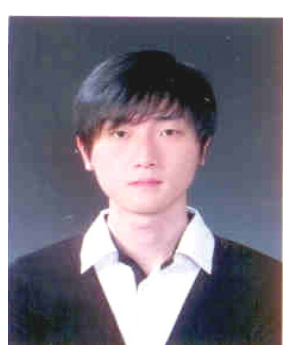

2010년 2월 한국산업기술대학 교 전자공학과 학사

2012년 2월 숭실대학교 전자 공학과 석사

2012년 3월 현재 숭실대학 교 전자공학과 박사과정 <관심분야> 무선통신 시스템, 고속 신호처리 회로 설계 


\section{임 원 규 (Won-gyu Lim)}

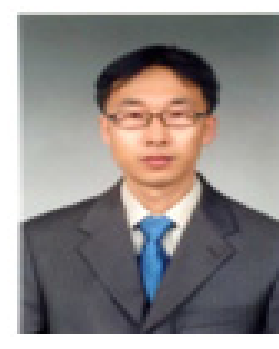

2002년 2월 경북대학교 전자공 학과 학사

2004년 8월 한국과학기술원 전 기 및 전자공학과 석사 2008년 8월 한국과학기술원 전

기 및 전자공학과 박사 2008년 9월 2009년 9월 한국 과학기술원 정보 연구소 근무

2009년 10월 현재 한국항공우 주연구원 위성전자 팀 재직

<관심분야> 인공위성 원격측정명령계, $\mathrm{RF}$ 통신시스 템, RFID 리더 통신 시스템, 전자파 진단 장치 시스템, $\mathrm{EMI} / \mathrm{EMC}$, 이동 통신 안테나

\section{김 종 훈 (Chong-hoon Kim)}

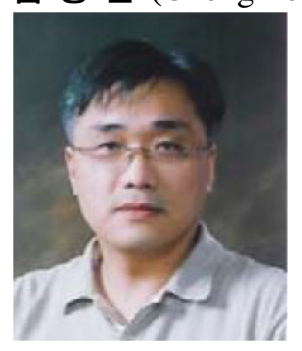

1984년 서울대학교 전자공학과 학사

1986년 서울대학교 전자공학과 학사

1993년 미국 Northwestern 대 학교 $\mathrm{EECS}$ 박사

1996년 현재 숭실대학교 정보

통신전자공학부 교수

<관심분야> 무선통신 시스템, 고속 신호처리 회로 설계 